\title{
INFLUENCE OF ISLAMIC PRECEPTS ON ENGINEERING \& ARCHITECTURE
}

\author{
by Ghulam Hassan Khan, M.Sc., (Harvard), M. ASCE..
} Srinagar. Kashmir

\section{DOI: http://dx.doi.org/10.5915/14-1-12125}

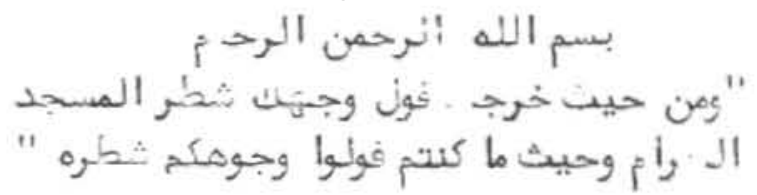

Wa min haisu kharajta fawalli wajhaka shatrul masjidil Haram: Wa haisu ma Kuntum fawalloo wujuhakum Shatrah:

Surah 2: Ayat 149.

Trans: Which ever way you depart, face towards the Holy Masjid, and wherever your are. face towards it. 1. The FIRST revolutionary change in the orientation of Islamic places of worship was brought about by this Quranic ordiance. It applied to humble structures as well as to magnificent edifices wherever located or whoever builds them.

The Kaaba, the First House of Gind, built by Hazarat Adam A.S is located at $50^{\circ}$ and $20^{\circ}$ lat in Mecca. Damaged during the deluge of Hazrat Noah A.s. its superstructure was reconstructed by the Prophet Ibrahim A.s. assisted by his eldest son Prophet Ismail A.s. When the Prophet Muhammed s.a.w.s. was 35 years of age the Kaaba was rebuilt. The black stone was put in its present position in one corner of the exterior wall by Hazrat Muhammad s.a.w.s.

Kaaba is a unique structure in the world $43 \mathrm{ft}, \mathrm{x} 42$ $\mathrm{ft}$. by $33 \mathrm{ft}$. in size, a cube, built in stones, with a flat reof, and invested with a drapery consisting of two parts, the Kamis (vest) and the I/arar (drawers) renewed once annually. The inner draping is red and the outer draping is black. The letters of Kalima Tayyiba i.c.

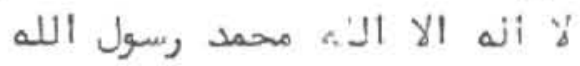

La Illaha illallahu Mohammadu Rasoolullah are woven into the body of these coverings, while the border is sometimes left blank and sometimes inscribed with verses from the Glorious Quran. Although several rennovations have taken place, the Kaaba has undergone no material changes. It stands in the centre of a large uncovered yard about $538 \mathrm{ft}$. $\times 355$ $\mathrm{ft}$. in sire. All around is a covered Masjid with a number of gates. The Masjid is being extended and enlarged both horizontally and vertically. Its various component parts, gates, pillars, and minaretes belong to different periods: the major part belonged to the Mamluke and Ottoman periods. The present phase of extensive remodelling and extension works has been taken up by the Saudi Government. By $1383 \mathrm{H}$ it had added 45,000 sq. yds. by acquiring houses. It can accommodate 400.000 persons at prayers.

The Bait-ul-Haram, the holiest of all Masajid is held in highest esteem by all Muslims. No one will sleep with feet turned towards the Qibla: even a dead body is not buried with feet facing the Qibla; No one can sit for easing oneself or for cleaning either with face or with the back turned towards the Qibla.

The orientation of graves. mausoleums. lavatories and bath rooms have to bear this restriction in view. 2. The Second Contribution was the replacement of pictures, figures and idols by calligraphic inscriptions and geometrical representations used on the interiors as well as exteriors of buildings. Elaborate quotations from the Quran are beautifully engraved in different scripts viz. Kufic and Cursive. On fragile and common articles Non-Quranic inscriptions are used instead. Two famous calligraphers associated with the development of Hashkhi script are 1. Ibn Muqla (d. 939 C). a minister of the Abbasid Caliph of Baghdad, and 2. Ibn Al-Bawwab (d. 1022 C). a painter. Calligraphy and its associated art. painting and decoration on the ceramic tiled interiors of Masajid rose to magnificent heights under the Timuri and Safavi rulers.

The Masjid, unlike any other religious building, has no liturgical focal point except for the Mihrab. which occupies the central point in the wall lacing the Qibla. The Imam, who leads the congregational prayers stands at this point. The Mihrab has taken the shape of a niche or an alcove. It is along the sides of Mihrab that Quranic verses from Sura Al-Jumaa are inseribed and engraved.

Since prayers have to be offered in straight rows, the average depth of a row being about 42 inches, the prayer hall has to be built as a rectangle. The prayers have to be offered in the 4 positions. 1 , standing. 2 . bending. 3. prostration and 4. sitting: there is, therefore. no furniture in the Masjid excepting the Mimber (pulpit) for the Imam.

Therefore, the entire desire to express artistically the love and adoration of Allah is channelled into the basic shape of the building and expressed in ceramic. mosaic and relief carvings. Kashmir has used the 99 beautiful names of Allah and other Quranic quotations on Khatambandi and paper mache on walls, ceilings and domes.

3. The Third important precept is the obligation of performing Wuzu (ablutions), as a pre-requisite. for offering prayers. In certain cases complete bathing is obligatory. This obligation made it necessary to 
arrange a supply of clean water within a reasonable distance Irom a Masjid. The Abbaside Queen, built a monumental hydraulic work. a conduit canal right up to Arafat where millions of Hajjis use its water. It bears her name the Zubaida Canal. In 1461 c Ghazi Khnsrobey had laid out public baths and water closets in Sarajevo (Bosnia). Akbar (1555-1605) built an intricate covered system of lifting water to Haripabat fort. These marvellous developments took place when France. England and Russia were primitive by comparison. London had its public water supply in 1611. Paris in 1661 and Moscow in 1861. U.S.A. was lirst colonized in 1607. Marvelous designs for providing comfortable spouts and tubs with smokeheating were evolved in Kashmir. Khankah-e-Mualla at Srinagar has a double-story bath house functioning even now. At Pakherpora. 1 was amazed to see an underground earthen unlined tunnel for conveying water to Karewa lands (of course no longer in use now). Near Rishipur I was struck when I saw underground vitrified pipe line apparently meant for conveyance of pure water or used water.

4. Islam enjoined calling the faithful to prayer not by ringing bells but by reciting Aran. An elevated spot had to be selected to make the call audible. This necessitated building a special feature which took the shape of Minar so distinctive of Islamic places of worship.

5. The Shape of Masjict: Islamic Architecture established a unity of style based on the requirements of facing the Qibla, the prayer hall being rectangular. a minaret for the Muazin and provision of water for ablutions. and evolved patterns that left visible stamps even when utilizing local materials. local talent and techniques suiting local conditions.

The earliest form of Masjid was the open plan following the layout first used by the Prophet $\mathrm{Haz}$. Muhammed s.a.w.s. himself at Madina. It consisted of a rectangular enclosure with a wall or a structure containing a Mihrab on the side facing the Qibla This became the prayer Hall. The other three sides had a mere wall to begin with followed by roofed aisles or arcades. A minaret was added on the left back corner. Jamia Masjid Delhi and Shahi (Pather) Masjid Srinagar are open plan types. The other types then followed. The four-lwan type and the Domed type. The four-Iwan type was favored in Iran. the most famous being the Masjid-i-Jami of Isfahan built in Seljuk period in early IIth century. Our Jamia Masjid of Srinagar is a four-Iwan type built by Sadraud Din Khurasani, Architect during the reign of Sultan Sikander (1394-1398 c). The Masjid is $384 \mathrm{ft} . x 381 \mathrm{ft}$. with an inner open yard of $254 \mathrm{ft} . \times 234 \mathrm{ft}$.

Domed Masajid are mainly associated with Turkey. The earliest example is the Talkatan Baba Masjid of Merv which dates to the end of the IIth century A.D. The Masjid, itself being rectangular in shape, draws together the entire structure under a central dome. To cover the rectangular area, attempts were made to have multiple small domes. The finest example of a domed Masjid is the Selimiye Masjid of Edirne. Turkey built in 1567-1575 and designed by the famous architect Sinon (1489-1586). The son of a Greek Christian stone mason. Sinon enrolled in the Turkish army. $\mathrm{He}$ had great skill in bridge-building. To him have been attributed 81 large Masajids. 51 small Masajids, innumberable libraries, palaces. Hamams. aquaducts, Mausoleums. Caravansarais. the fountains. The Suleimany Masjid in Istanbul and the Silimiye Masjid of Edirne are his masterpieces.

\section{Great Engineering Feats:}

Joseph Macabe in "The Splendour of Moorish Spain" says: "In the I0th century. Cordova had a population of a million souls, a lavish supply of pure water and miles of well-paved and lamp-lit streets .... There was not (at that time) anywhere in Europe, outside Arab Spain and Sicily, and there would not be for at least two centuries, a single city with 30.000 people, with even the most rudimentary sewerage. with any paved or lamp-lit streets, with a communal supply of pure water, with an elementary regard for hygiene. with a single public bath (and few, if any. private baths) or school, and with even moderately good precautions against theft and violence" (Ref: $p$. 37 Splendours of Islam-Wilfred Blunt. Angus and Robertson Publishers - U.K.)

Muslims, everywhere, absorbed something of the culture of freshly converted people, blending it with their own to make Islam a rich and an enduring culture as well. In turn even Nomads from Khirghiz steppes the seljuk Turks and fresh converts to Islam produced great builders like Alp Arslan (1063-72) and Malik Shah (1072-92). The problem of setting a circular dome upon a rectangular base was solved by the Seljuk architects and the magnitude of their achievement was acknowledged by Eric Schroeder in these words: -

"European dome builders never approached their skill. How ingeniously the Western builder compensated his ignorance of the mechanics of dome construction is attested by the 10 chains round the base of St. Peter's and the concealed cone which fastens the haunch of St. Paul's. But engineers could not hope to prescribe an ideally light dome of plain masonry before Newton's work on the calculus. The Siljuks. however. had solved the difficulties which Wren avoided. Not that they knew anything of the calculus: Their knowledge was empirical. But by courageous experiment and intelligent observation of failure the Suljuks built .... what is practically the ideal dome, made possible by the advance of mathematical science in the eighteenth (century)" (Ref: p. 41. Splendours of Islam. Wilfred Blunt)

Alhambra - the Moorish palace of Granada. Spain, has arches around the courts which are a classic 
feature of Islamic architecture. Richard Ford, who visited it in 1830. has this to say about it: "Lightness was the aim of Moorish architects, as massiveness was the aim of the ancient Egyptians. The real supports were cancelled, and purposely kept unexpressed, so that the apparent supports, their pillars. and gossamer perforated fabric, seemed fairy work: the object was to contradict the idea of weight. and let the masses appear to hang in the air floating like summer clouds". This ambition is perhaps most spectacularly realized in the roof of the chamber of the two sisters, a "fantastic honeycomb of hanging stalactites" which seems the work of bees rather than of man. The plain exterior of the building gives little hint of this opulence within" (Ref: p. 67. Splendours of Islam, W. Blunt.) 7. The contribution was not confined to religious edifices only but to secular monuments and works of public utility like gardens, bridges, roads, canals, pavillions, observatories and to palaces, forts, tombs and mausoleums. The Allahverdi Khan bridge, which connects 1sfahan with the Armenian suburbs of Julfa. is 300 yards long and "a noble piece of engineering". The Khwaju bridge, built in the time of Shah Abbas 11 (c 1650) is at once a bridge and a dam. It had six semioctagonal pavillions.

It is a paradox that the so-called semi-barbarous nomads from the wastes of central Asia, should turn from great destroyers into greater creators and builders after embracing Islam.

Islamic architecture existed in India before Babur laid the foundation of Mughal Dynasty in 1526. Three centuries earlier the Qutub Minar in Delhi was built to a height of $238 \mathrm{ft}$. in $1193 \mathrm{c}$. Until then the Iranian element was stronger than the native.

Kashmir sultans had built Zainlank in the center of the largest fresh water lake in Asia - the Wuller: Zainadab - a 12 story building reputed to have had 600 rooms: Khankahi Mualla, Jamia Masajid, and Budshah's Dumat - Domed Mausoleum of the mother of Zainul Abidin (1421-1472).

The Mughals built superb palaces. in Delhi. Agra. Lahore and Fatehpore Sikri. They are masterpieces in red sandstone and white marble combining the architectural features of Iran and India. Superb pleasure gardens were created by them in Kashmir.
They carried on the Timuri tradition of living outdoors and built the Shalimar. Nishat, Chashmasahi and Naseem Bagh, around the Dal lake of Srinagar: and Verinag and Achabal spring gardens in south Kashmir. They also built the Hari Parbat Fort. The Shahi Masajid and an observatory at Pari Mahal.

8. Kashmir sultans evolved a remarkable feature, an unusual pointed spire, locally called BRENG. which crowns the Ziarats, Khankahs and mosques of the Kashmir valley. The prevailing notion that this unique and distinctive form of Kashmir architecture owes its origin to Buddhist influence has been discounted by Percy Brown in Chapter XV of "Indian Architecture - Islamic Period".

According to him:

-The form of Kashmir architecture is very similar to timber construction of other mountainous countries like Scandinavia and the regions of the Alps .... in the wooden churches of Norway of the 11th to the 14th centuries, there are the sloping roofs in tiers so as to form a kind of pyramid, with gables and over-hanging caves, each surface water-proofed with layers of birchbark, every feature of which has its counter-part in the wooden shrines and Ziarats of Kashmir. Then the chalets of the Austrian tyrol with their projecting upper stories, balconies with carved railings. and casement windows bear familiar resemblance to the old houses of Srinagar." Perey Brown concludes that "the analogies of style could obviously not be duc to any common origin because Kashmir is so far away from the European countries. This must be duc to similar climatic conditions and availability of similar types of materials".

The most distinctive feature. common to all the Masajid, the large central dome, smaller domes on the four sides. and the Minarets evolved, in my view, from the very shape of the word Allah written in Arabic. combined with the letters of Kalima written in Kufic script. The most remarkable example shows the Kalima written both from right to $\mathrm{lcft}$, as in use in Arabic script. and also from left to right (which is most unusual). The letters are all crowned with little domes and pointed spires. 